\title{
A fungal community in plant tissue from the Lower Coal Measures (Langsettian, Lower Pennsylvanian) of Great Britain
}

\author{
MichaEL KRINGS, NORA DOTZlER, ThOMAS N. TAYLOR \& JEAN GALTIER
}

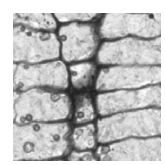

\begin{abstract}
A diverse assemblage of microfungal remains occurs in periderm cells of a lycophyte from the Lower Coal Measures (Carboniferous) of Great Britain. Among the remains are several types of hyphae, including septate forms with catenulate swellings and small, narrow forms that are multi-branched. There are also several types of spherical structures that differ from one another in size, wall thickness, and ornamentation. The most common of these is interpreted as peronosporomycete oogonia based on specimens with attached antheridia. Other forms may also represent Peronosporomycetes, but might as well belong to the Zygomycota. Oval or tear drop-like structures that occur in clusters or chains are interpreted as conidia. Host reactions in the periderm cells are rare, with the exception of small callosities. Although it is not possible to conclusively identify the (precise) systematic affinities of the fungi, this discovery is significant because it demonstrates that one of the most common plant tissues in the Carboniferous (i.e. lycophyte periderm) provided a suitable habitat for several endophytic organisms at the same time. The overall excellent preservation of the host tissue, together with the evidence of host reactions, indicates that at least some of the endophytes were biotrophic. - Key words: arborescent lycophyte, Carboniferous, coal ball, fossil fungi, host response, periderm, Peronosporomycetes.
\end{abstract}

Krings, M., Dotzler, N., TAYlor, T.N. \& GAlTiER, J. 2010. A fungal community in plant tissue from the Lower Coal Measures (Langsettian, Lower Pennsylvanian) of Great Britain. Bulletin of Geosciences 85(4), 679-690 (5 figures). Czech Geological Survey, Prague. ISSN 1214-1119. Manuscript received September 1, 2010; accepted in revised form November 12, 2010; published online December 1, 2010; issued December 20, 2010.

\begin{abstract}
Michael Krings (corresponding author) \& Nora Dotzler, Department für Geo- und Umweltwissenschaften, Paläontologie und Geobiologie, Ludwig-Maximilians-Universität, and Bayerische Staatssammlung für Paläontologie und Geologie, Richard-Wagner-Straße 10,80333 Munich, Germany; m.krings@lrz.uni-muenchen.de, hase42@gmx.net• Michael Krings \& Thomas N. Taylor, Department of Ecology and Evolutionary Biology, and Natural History Museum and Biodiversity Research Center, The University of Kansas, Lawrence KS 66045-7534, U.S.A.; tntaylor@ku.edu•Jean Galtier, AMAP, UMR 5120 CNRS, CIRAD TA A-51/ PS2, Boulevard de la Lironde, 34398 Montpellier, France; jean.galtier@cirad.fr
\end{abstract}

The level of complexity attained by ecosystems today represents a key area of ecological research (Green \& Sadedin 2005), and one of the measures used to define this complexity is the patterns and processes resulting from associations and interactions between individuals, populations, species, and communities (Colwell 1998). This focus has initiated questions at several levels as to how these associations and interactions may have evolved. Answers to date have primarily come from analyses of modern systems. However, where preservation and preparation techniques permit detailed assessment, the fossil record is becoming increasingly important as the only method of documenting associations and interactions within an evolutionary context.

It has been suggested that associations between fungi (in the broad sense of including members of the Peronosporomycetes and Hyphochytridiomycota) and land plants were highly diverse and complex in Carboniferous ecosystems (Taylor \& Krings 2005) based on the fact that all major lineages of fungi, as well as several groups of fungus-like microorganisms, were in existence by this period of time (e.g., Heckman et al. 2001, Bhattacharya et al. 2009). Moreover, intricate land plant-fungus interactions have existed long before the Carboniferous (Taylor et al. 2004). In addition, many Carboniferous plants were long-lived and complex in morphology and internal organization (Taylor et al. 2009), and thus have provided multiple contact sites and ecologically distinct (micro-)habitats for fungi. Finally, the vast coal swamp forests were highly productive ecosystems, and thus provided an abundance of biomass for saprotrophic fungi.

To date evidence of Carboniferous land plant-fungus associations is relatively rare. This is especially true of complex associations, in which different fungi co-occur in 
a single host plant (Krings et al. 2007, in press b). The scarcity of descriptions of fungi associated with Carboniferous plants is due in part because the most common types of fossils from this period of time (i.e. impressions, compressions) do not normally provide sufficient resolution to detect the presence of fungi. On the other hand, even the most common mode of structural preservation (i.e. coal balls) of Carboniferous plants has yielded relatively few studies of fungi (see Stubblefield \& Taylor 1988, Taylor \& Krings 2005). One important reason for this is the commonly used cellulose acetate peel technique. Since this technique relies on the acid digestion of the coal ball matrix, many of the fungi embedded in the matrix are lost during preparation.

The Coal Measures of Great Britain have provided evidence of well-preserved Pennsylvanian coal ball floras, which have been studied intensively and documented for more than 100 years, most notably by E.W. Binney and W.C. Williamson (see Galtier 1997). Co-occurring with the plants are various types of fungi. Although the presence of fungi in the coal balls was noted in several early studies, including Cash \& Hick (1879), Williamson (e.g., 1880, 1881, 1883), Weiss (1904), and Ellis (1918), their diversity and significance as ecosystem constituents have not been fully appreciated.

This paper reports on a community of fungi composed of various types of hyphae and propagules that occurs within lycophyte tissue from the Lower Coal Measures (Bashkirian/Lower Pennsylvanian) based on a thin section preparation in the collection of the late Prof. Max Hirmer of Munich, Germany. Although the systematic affinities of the fungi and the biological nature of their relationship(s) with the host plant cannot be fully evaluated, this discovery provides new information on the diversity of land plant-fungus associations in the Carboniferous, and thus helps to formulate or refine ideas about the levels of biological complexity and their evolution in ancient ecosystems.

\section{Material and methods}

The material used in this study comes from a single thin section preparation that was prepared by W. Hemingway from a coal ball collected in the Lower Coal Measures of Great Britain. The provenance of the coal ball is not documented on the slide, but since the slide belongs to a set of
Hemingway and Lomax slides labeled Dulesgate or Halifax it is clear that the specimen comes from either of these two localities. Dulesgate is one of the Lancashire localities where the Union Seam was the source of the coal balls that were initially described by Binney (1865). Coal balls from Halifax (Yorkshire) were collected from the Halifax Hard Seam, which is regarded as a stratigraphic equivalent to the Union Seam. Both coal seams have been dated as Westphalian A or Langsettian (Bashkirian, Lower Pennsylvanian). The Union and Halifax Hard seams, together with the contemporaneous Bouxharmont Seam in Belgium and the Finefrau-Nebenbank Seam in the Netherlands and Germany, represent the source strata of the richest European coal-ball floras (Galtier 1997).

The Union and Halifax Hard seams were two of the principal sources of coals balls used by Lomax and Hemingway, among others, in the preparation of commercial thin sections of Carboniferous plant fossils from Great Britain that were subsequently sold worldwide (Howell 2005). Thin sections were prepared according to standard procedures (for details, see Hass \& Rowe 1999) in which a piece of the coal ball was cemented to a glass slide and subsequently ground with an appropriate abrasive until it was thin enough to be examined in transmitted light.

The slide containing the infected lycophyte periderm described in this paper belongs to the teaching collection of the late Prof. Max Hirmer that today is deposited in the palaeobotanical collection of the Bayerische Staatssammlung für Paläontologie und Geologie in Munich, Germany, under acquisition BSPG 1964 XX 25. The slide was analyzed using normal transmitted light microscopy equipment; digital images were captured with a Leica DFC-480 camera.

\section{Results}

One of the plant remains in the slide is a piece of lycophyte periderm approximately $1.5 \mathrm{~cm}$ long by $0.4 \mathrm{~cm}$ wide. In an oblique section, cells of the periderm are rectangular, arranged in distinct files, with each cell approximately $400 \mu \mathrm{m}$ wide and $100 \mu \mathrm{m}$ high (Fig. 1A, B). There are apparently no regions within the tissue that contain intercellular spaces. Extending throughout the tissue are several morphologically different types of intracellular microfungal remains, which may occur scattered (Figs 1C-I, 2A-L,

Figure 1. A, B - oblique section of lycophyte periderm from the Lower Coal Measures of Great Britain, showing the arrangement of thin-walled cells and numerous microfungal remains; bars $=200 \mu \mathrm{m}$. $\bullet \mathrm{C}$ - detail of periderm cells showing various types of spherical structures; arrows indicate massive-walled type 2 individuals associated with host cell walls; bar $=50 \mu \mathrm{m}$. $\bullet \mathrm{D}$ - close up of periderm cells containing type- 1 spheres; arrow indicates short fragment of subtending hypha; bar $=20 \mu \mathrm{m}$. $\bullet$ E - catenulate hyphae with irregular swellings and constrictions; arrow indicates branch hypha terminating in a large thin-walled sphere (type 5); bar $=10 \mu \mathrm{m} . \bullet \mathrm{F}-\mathrm{H}$ - same type of hypha as in Fig. 1E, showing details of irregular swellings, constrictions, and (pseudo-)septa; bars $=5 \mu \mathrm{m}$. $\bullet \mathrm{I}$ - cluster of narrow, multi-branched hyphae; bar $=5 \mu \mathrm{m}$. 


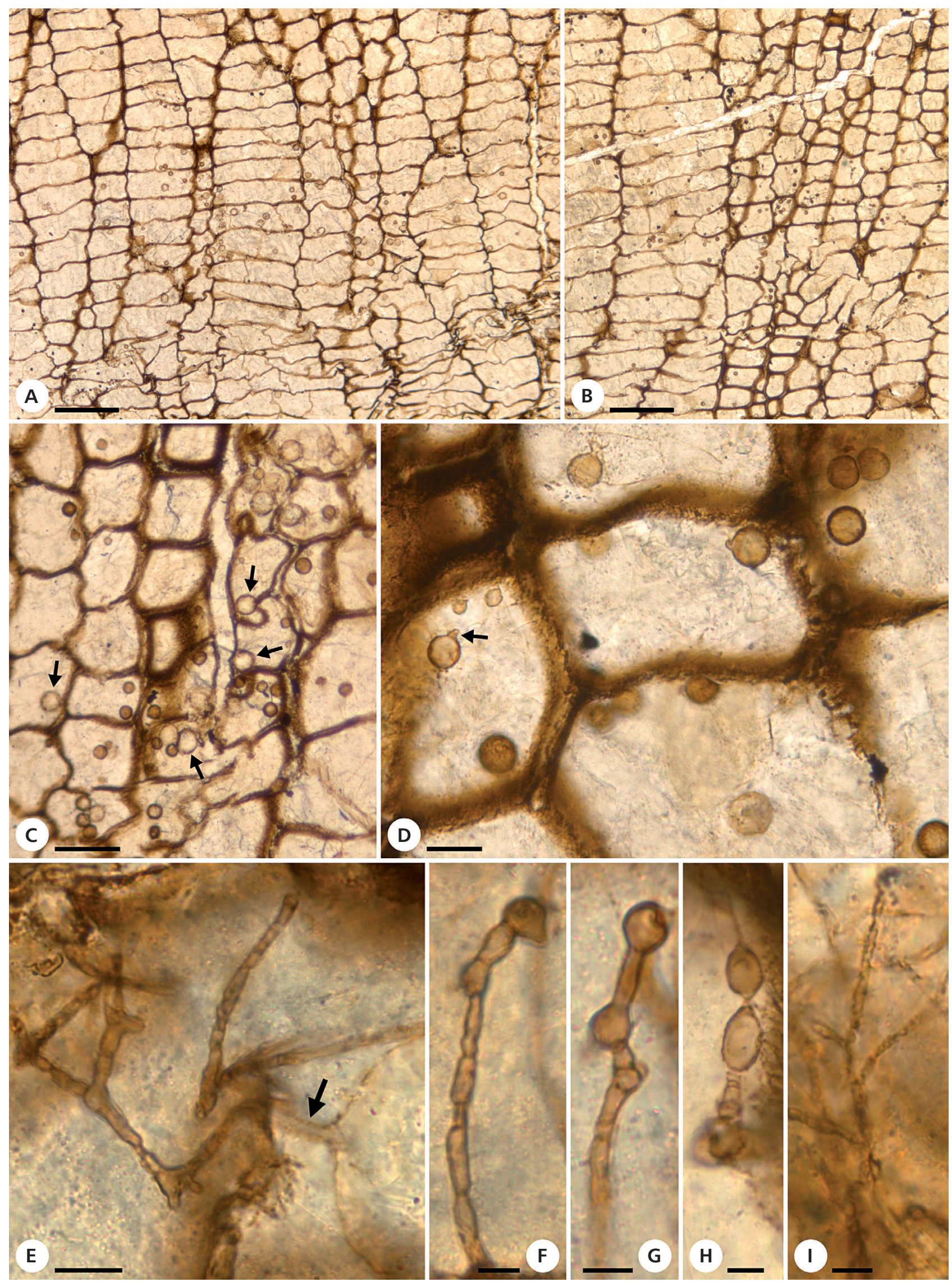


3A-J, 4A-M) or clustered (Fig. 5A-E) in regions of the periderm.

\section{Hyphae}

From this single section it appears that the most common form of hypha is septate or pseudoseptate, and from 1 to $5 \mu \mathrm{m}$ in diameter (Fig. 1E-H). Hyphae consist of numerous catenulate swellings that alternate with more or less distinct constrictions in which the (pseudo-)septa are located. The size and morphology of the swellings varies within a single hypha, from pronounced and spherical-ovoid (Fig. 1G, H) to indistinct and rod-shaped (Fig. 1F). Branching occurs repeatedly in this type of hypha, so that loose aggregations are formed. In one instance, a branch hypha terminates in a large, thin-walled sphere (arrow in Fig. 1E). Similar spheres have also been found isolated in some of the cells (Fig. 4F).

A second type of hyphae in the periderm cells is more delicate (up to $1 \mu \mathrm{m}$ in diameter) and probably aseptate (Fig. 1I). Some specimens show more or less pronounced hyphal constrictions, but these hyphae lack swellings. We are uncertain whether these constrictions are the result of fossilization (i.e. a shrinkage artifact), or are a reflection of the presence of (pseudo-)septa. In a few periderm cells there are dense, peg-like clusters of delicate hypha around regions of host cell walls that are ruptured (Fig. 2I). These hyphae appear to be regularly segmented, either by septa or simple constrictions, but are too narrow to allow for a more detailed analysis.

\section{Reproductive structures and propagules}

Within many of the periderm cells are one to multiple spherical, ovoid, or drop-shaped structures, between $<5$ and $\sim 35 \mu \mathrm{m}$ in diameter, which we have informally classified into six different morphotypes (type 1 through 6 ) based on size and shape, degree of opaqueness, wall thickness, and surface ornament. The different morphotypes co-occur in the periderm (sometimes even in the same cells), but vary in the number of specimens.

Type 1. - The most abundant (>100 specimens) type of spherical structure ranges from 5 to $15 \mu \mathrm{m}$ in diameter, is translucent to brown in the fossil, and characterized by a smooth (psilate) wall (Figs 1D, 2A-F). Most of these spheres are solitary and lack evidence of attachment to the host cell wall and/or parental hypha (Fig. 2A, B). In some, however, there is a distinct extension that may represent an attachment point to the subtending hypha (arrows in Figs 1D, 2D), while in a few the actual subtending hypha is intact, demonstrating that the spheres were originally attached to the host cell wall (Fig. 2E, F). Distinct septa are evident in some of the hyphae that attach the spheres (arrow in Fig 2F); some spheres appear to have been intercalary based on the presence of two hyphal remnants on opposite sides (arrow in Fig. 2A). The specimen illustrated in Fig. 2C is particularly interesting with regard to suggesting possible affinities of these propagules. It shows a smoothwalled spherical structure of the same size and morphology as those noted earlier, to which are attached four club-shaped terminal swellings of narrow hyphae, each approximately $3-4 \mu \mathrm{m}$ in diameter; the arrow in Fig. $2 \mathrm{C}$ indicates that there is a distinct septum at the base of one of the swellings.

Type 2. - There are other, less abundant ( $<100$ specimens) spherical structures in the periderm that are distinctly larger (i.e. up to $30 \mu \mathrm{m}$ in diameter), may occur solitary or in small clusters of up to six individuals, and are typically associated with a host cell wall (Fig. 3A-J). These spheres are distinguished from all other fungal remains in the periderm by a massive, non-layered outer wall or wall component up to $5 \mu \mathrm{m}$ thick with an irregularly wrinkled outer surface. This outer wall or wall component appears to be ephemeral (evanescent) because in most specimens it is partially degraded (e.g., Fig. 3B, D, E); in a few specimens, the outer wall or wall component is (largely) absent, leaving a translucent, thin- and smooth-walled (arrow in Fig. 3A) or finely ornamented (Fig. 3B) sphere. We interpret the wall of this sphere as the persistent wall (or wall component) that delimits the outer surface of the propagule. Most specimens of this type are broadly attached to the inner surface of the host cell wall; Fig. 3C, D demonstrate the broad attachment region that appears to be formed by the sphere's massive outer wall or wall component, which perhaps was mucilaginous or contained some adhesive properties that allowed the spheres to attach to the host

Figure 2. A, B - smooth-walled type-1 spheres in periderm cells; arrow in Fig. 2A shows a sphere that formed in an intercalary manner, arrows in Fig. 2B indicate type- 1 spheres interpreted as being immature based on thinner and more translucent wall (note single verrucate type-3 sphere in upper left of Fig. 2A); bars $=20 \mu \mathrm{m}$. $\bullet \mathrm{C}$ - smooth-walled type- 1 sphere interpreted as peronosporomycete oogonium with four attached paragynous antheridia; large arrow indicates oogonial stalk, small arrow shows septum between antheridium and antheridial hyphae; bar $=5 \mu \mathrm{m}$. $\bullet \mathrm{D}-$ type-1 spheres; arrow indicates fragment of subtending hypha; bar $=10 \mu \mathrm{m} . \bullet \mathrm{E}, \mathrm{F}-$ stalked type -1 spheres; arrow in Fig. 2F indicates septum; bars $=5 \mu \mathrm{m}(\mathrm{Fig}$. 2E) and $10 \mu \mathrm{m}(\mathrm{Fig}$. 2F). - G, H, J-L - type-4 structures interpreted as chains or clusters of conidia; arrows in Fig. $2 \mathrm{H}$ show areas where the conidia will disassociate, arrows in Fig. $2 \mathrm{~K}$ and $\mathrm{L}$ indicate a beak-like region that may represent the point of attachment to other conidia or some type of discharge tube; bars $=5 \mu \mathrm{m}$ (Fig. 2G, H, J) and $10 \mu \mathrm{m}$ (Fig. 2K, L). $\bullet \mathrm{I}$ - aggregation of narrow, multi-branched hyphae; bar $=10 \mu \mathrm{m}$. 
Michael Krings et al. • A fungal community in plant tissue from the Lower Coal Measures of Great Britain

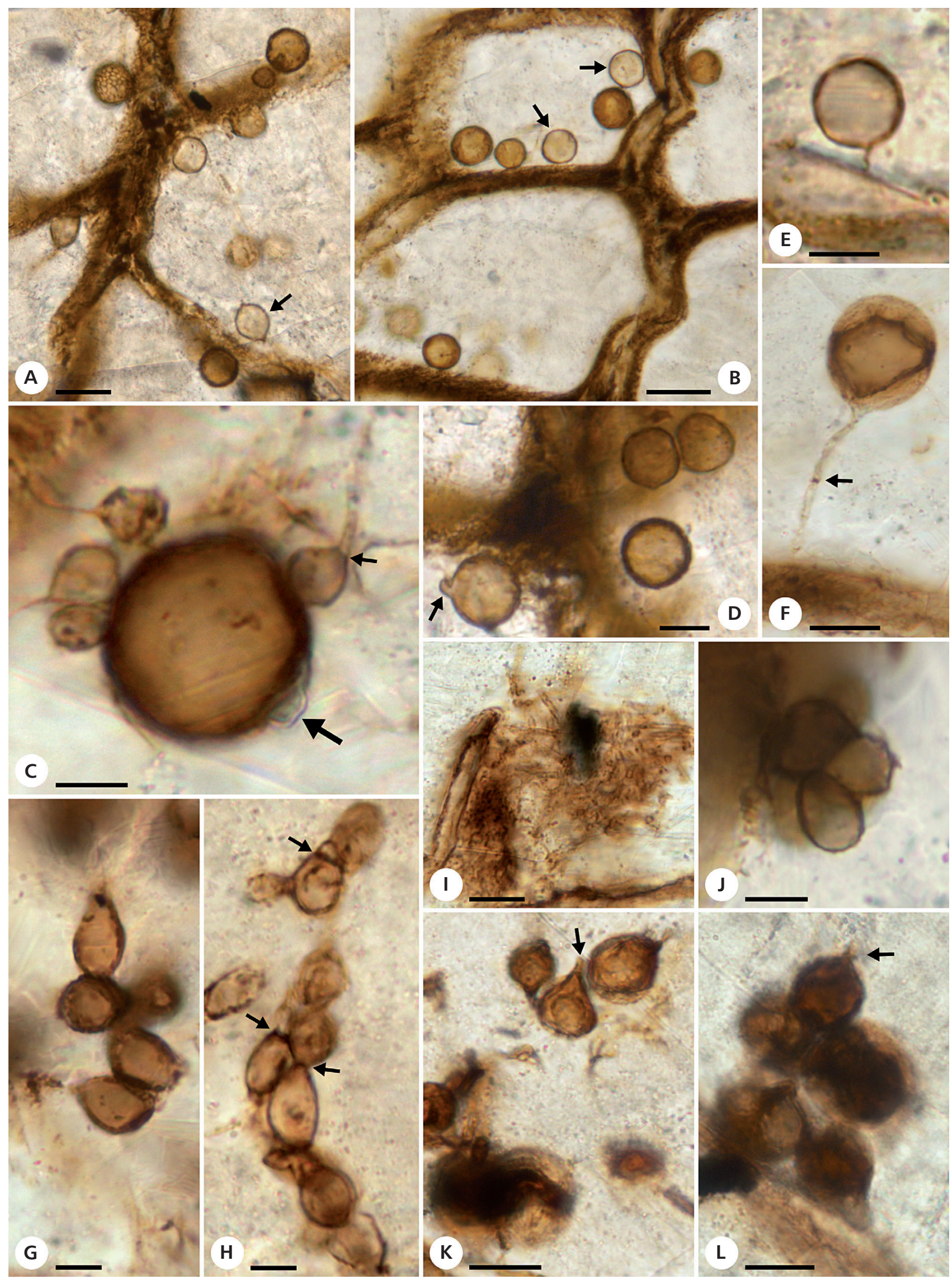


walls. Other specimens of this morphotype are attached to the host cell wall by a narrow stalk (Fig. 3G), while one specimen appears to be anchored within the host cell wall (Fig. 3J). In spheres that are attached to the host cell wall, the actual propagule is characterized by an extension that is directed toward the point of attachment (Fig. 3C, D). This region is rather inconspicuous in the specimens adhering to the surface of the host cell wall, but prominent in the specimen that is embedded in the host cell wall (e.g., compare Fig. 3D with $3 \mathrm{~J}$ ). We estimate that approximately $50 \%$ of the massive-walled spheres are closely associated with, and most likely also physically attached to, a slightly or distinctly smaller and more opaque, smooth-walled spherical structure (e.g., arrows in Fig. 3E, F). In one specimen there appears to be a circular pore in the small sphere through which an organic connection with the large sphere is maintained (arrow in Fig. 3I). Moreover, in several specimens a narrow dark line between the two spheres (Fig. 3F - lower sphere) may represent either a hypha or some type of filament, or is a wall remnant of the smaller sphere.

Type 3. - This morphotype is slightly less abundant than type 2 ( $<<100$ but $>10$ specimens). Specimens are approximately $15-25 \mu \mathrm{m}$ in diameter, and represent the most easily recognizable spherical structures in the periderm due to a prominent, verrucate surface ornament (Fig. 4A-E). The wall of these spheres appears to be thin and translucent. Verrucae form a regular pattern of penta- to heptagonal (usually hexagonal) fields (e.g., Fig. 4B), each of which ranges from 1 to $3 \mu \mathrm{m}$ in width. Many of these spheres ( $25 \%$ of specimens) are closely associated with, or perhaps in organic attachment to, smaller, smooth-walled spherical structures, which are between 7 and $15 \mu \mathrm{m}$ in diameter and may be thin-walled and translucent (Fig. 4E right side of image) or relatively thick-walled and more opaque (Fig. 3E - left side of image). The presence of subtending hyphae/filaments on both the large and small spheres in several specimens indicates that neither sphere is a derivative of the other (arrows in Fig. 4C).

Infrequent types (types 4-6) and host reactions. - While the types of structures previously described are present in the periderm in (relatively) large numbers, there are also several interesting microfungal remains that occur infrequently or sporadically. One of these types (type 4) is represented in Fig. 2J-L. This type consists of ovoid to drop-shaped structures up to $15 \mu \mathrm{m}$ long and $13 \mu \mathrm{m}$ wide that may occur in clusters (e.g., Fig. 2J, L) or bead-like chains (Fig. 2G, H). In most chains of these cells it is possible to identify slightly constricted and more opaque regions that probably represent septa between the individual units (arrows in Fig. 2H). Some of the type-4 structures occurring in clusters appear stalked and arise from a common point on the host cell wall (Fig. 2L). Several of the drop- shaped bodies possess a beak-like region that may represent either the point of attachment to other units, or some type of preformed discharge tube (arrows in Fig. 2K, L). A small spherule is present in the interior of one of the drop-shaped structures illustrated in Fig. 2K (below the arrow). Other infrequent microfungal remains consist of a variety of thin-walled structures that may be variously attached to the host cell wall. One type (type 5), up to $33 \mu \mathrm{m}$ in diameter, is relatively large and always appears as a perfect sphere (Fig. 4F). Another of these specimens appears organically attached to the catenulate hyphae occurring in the periderm (arrow in Fig. 1E). Other thin-walled structures (type 6) are smaller, spherical to pear-shaped, and typically distorted (Fig. 4G-I); some specimens possess what appears to be a discharge pore (arrows in Fig. 4H, G). These thin-walled structures always occur in clusters and are confined to single host cells or small groups of adjacent cells. One (Fig. 4J) has an internal membrane and a structure that appears to be an infection peg that penetrates the host cell wall (arrows in Fig. 4J). At the base of the infection peg on the inner surface of the cell wall is a thickened region that is interpreted as an early stage in the formation of a host reaction callosity (also called an apposition, lignotuber, or papilla, among other terms; see Stubblefield et al. 1984). In the immediate vicinity of this structure is a second, well-developed tube-like callosity (Fig. 4J - left side of image). There are other host cell walls in the periderm that display one to multiple callosities, which are cone-shaped, densely opaque, and up to $7 \mu \mathrm{m}$ long (Fig. $4 \mathrm{~K}-\mathrm{M}$ ). In the section of periderm on this slide, however, the presence of callosities is relatively rare.

Concentration of fungal remains. - Despite the uniformity of the periderm cells, there is one small region that consists of approximately 20 cells in which fungal remains are highly concentrated (Fig. 5A-E). In these cells there are three general types of fungal remains, including tubular and catenulate hyphae with prominent spindle-shaped to oval swellings (arrows in Fig. 5A, E), uniform spores (conidia?) similar to the type-4 form described above but smaller (Fig. 5A, B, E), as well as larger, smooth-walled spheres similar to the type-1 morphology, each with one or two hyphal remnants suggestive of terminal or intercalary formation (Fig. 5C).

\section{Discussion}

Although there is one report of a diverse fungal assemblage from the periderm of a lycophyte from the Middle Mississippian of France (Krings et al. 2007), this paper provides the first report of morphologically diverse microfungal remains in lycophyte periderm from the Pennsylvanian. During the last several years we have examined the microorganisms (mostly fungi and fungus-like organisms) associated 

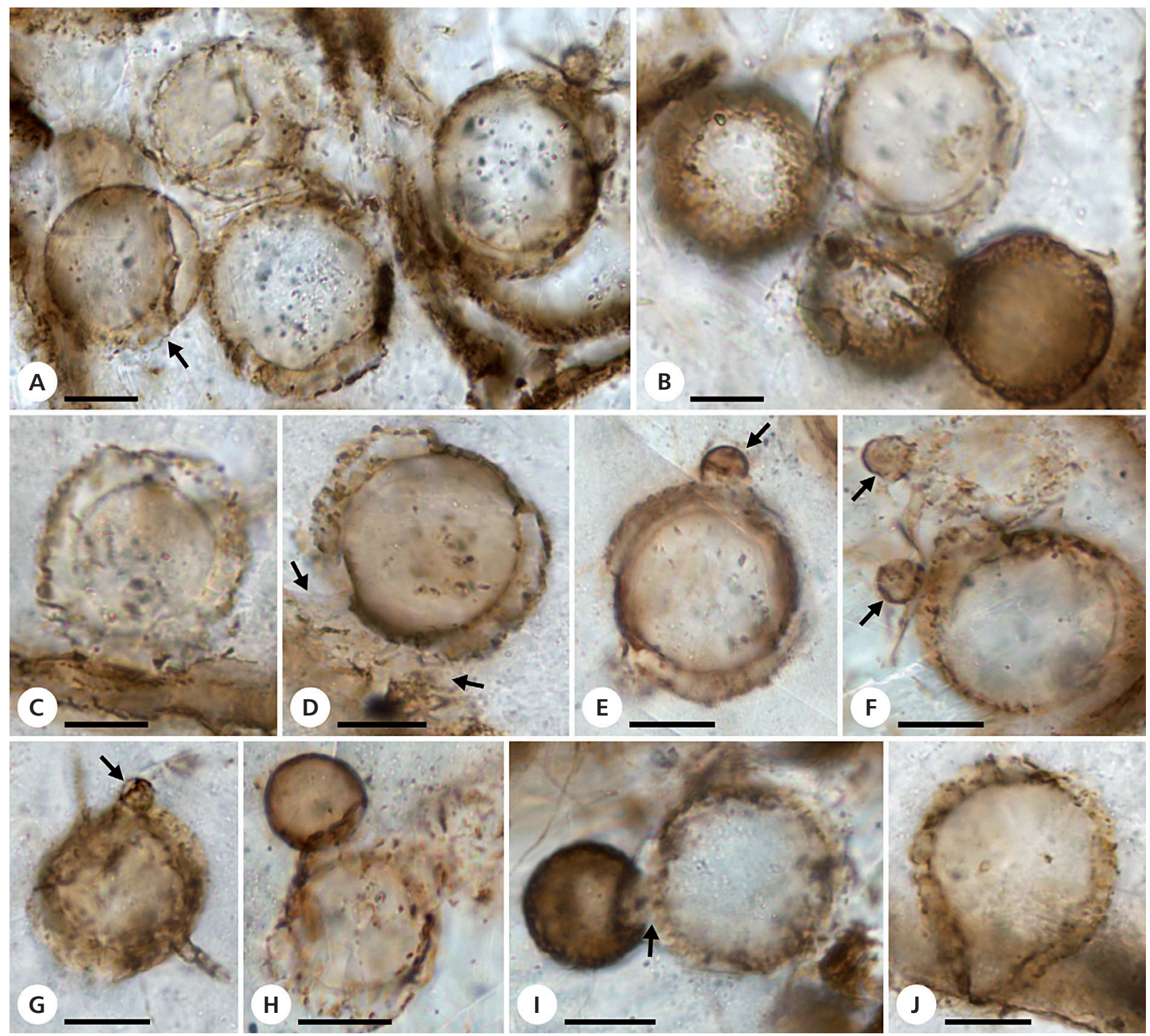

Figure 3. A-J - massive-walled type- 2 spheres; bars $=10 \mu \mathrm{m}$. A - cluster of spheres with the arrow indicating one sphere in which the evanescent wall or wall component is almost completely gone. $\bullet \mathrm{B}$ - sphere showing partially disintegrated outer wall or wall component; note the three spores below in which the outer wall is absent. $\bullet \mathrm{C}, \mathrm{D}$ - spheres showing broad attachment to host cell wall; arrows in Fig. 3D show region where outer ephemeral wall is partially fused with host cell wall. $\bullet \mathrm{E}-\mathrm{G}$ - spheres showing attached single, small sphere (arrows); note the delicate structure between the lower large and small spheres in Fig. $3 \mathrm{~F}$ and the subtending hypha in Fig. 3G. $\bullet \mathrm{H}, \mathrm{J}-$ type-2 spheres to which are attached smaller, single spheres that are larger than those in Fig. 3E-G; arrow in Fig. 3I indicates what appears to be an organic connection between the large and small spheres. $\bullet J-t y p e-2$ sphere with nearly complete outer wall showing truncated point of attachment that is integrated in host cell wall.

with Carboniferous plant remains preserved in cherts and coal balls from France, Germany, and Great Britain based on thin section preparations from the Renault and Roche collections in Paris, France, and the Hirmer collection in Munich, Germany. While evidence of the presence of fungi (e.g., hyphae, spores etc.) was encountered in nearly every slide, the high concentration and structural diversity of fungal remains have to date only been discovered in lycophyte periderm. This provokes the question as to whether lycophyte periderm may have represented an especially suitable habitat for microfungi. Although this question is difficult to address, especially when there are only two recorded occurrences, we still find the abundance of microfungi in this type of tissue as opposed to other types of plant remains interesting. Arborescent lycophytes were important elements of the vegetation in Euramerica during a considerable part of the Carboniferous (e.g., Kerp 2000). Lycophyte periderm occurs in virtually every coal ball from Lancashire and Yorkshire, and sometimes may represent the only plant tissue present. Phillips et al. (1985) estimated that $91-95 \%$ 
of the biomass preserved in the Union Seam coal balls (Lower Coal Measures, GB) was produced by lycophytes, including Diaphorodendron vasculare, Lepidodendron hickii, Lepidophloios fuliginosus, Bothrodendron mundum, as well as species of Paralycopodites and Sigillaria (Galtier 1997). We speculate that the simple abundance of periderm in these ecosystems, irrespective of whether the tissue was dead or alive, together with the fact that the cells of this tissue are characterized by thin walls, may have made this tissue a preferred habitat for fungal colonization.

It is equally difficult to evaluate the nature of the biological relationship between the endophytes and the host because of the incompleteness of both the host plant and fungi. The endophytes could have been either biotrophic or saprotrophic. The only evidence of a biotrophic (parasitic) relationship occurs in the form of two types of small callosities found in several of the cortical cells (Fig. 4J-M). Callosities represent inwardly directed projections consisting of newly synthesized wall material that are formed by living plant cells (but also by certain fungal spores; see Hass et al. 1994) in response to invading fungi or some other biotic cause. Callosities encase the fungal infection hypha or filament, and it is widely believed that they are effective in preventing or retarding penetration by the parasite (e.g., Aist 1977, but see Moerschbacher \& Mendgen 2000). This type of host reaction has been observed in cells of numerous extant plants (e.g., Young 1926, Archer \& Cole 1986, Rioux \& Biggs 1994), but is also known to occur in several fossil plants, including a lepidodendralean lycophyte and a zygopterid fern from the Carboniferous of France (Krings et al. 2009, in press a). Unfortunately, the cone-shaped callosities described here (Fig. 4K-M) cannot be conclusively associated with a single fungus in the periderm. In one host cell, however, there is evidence of the early formation of a tube-like callosity that surrounds the proximal portion of a penetrating hypha (arrows in Fig. 4J) adjacent to a well-developed tube-like callosity (Fig. 4J left side of image).

Another dimension of uncertainty involves the actual diversity of the endophytic microfungi in the periderm. It is difficult to accurately record the number of different types of biological species because the types of fungal remains within these tissues may not all represent separate species, but rather different developmental or life history stages of the same organism. Conversely, it is also possible that the individual morphotypes each represent several morphologically similar species. In spite of this, we feel confident that there are several forms that possess a consistent complement of features, which makes it possible to distinguish them from other forms. One of these are the spherical forms that possess a highly verrucate surface ornamentation pattern (type 3; Fig. 4A-E). A second type is also spherical and delimited by a massive outer wall or wall component (type 2; Fig. 3A-J) that appears to be evanescent based on several specimens that show various stages of wall disintegration (arrow in Fig. 3A). The third distinguishable type (type 1) has a smooth wall that is opaque and relatively thick at maturity (Figs $1 \mathrm{D}$ and $2 \mathrm{~A}-\mathrm{F}$ ). We hypothesize that the slightly smaller and more translucent specimens (arrows in Fig. 2B), which consistently occur with the larger smooth-walled spheres, represent earlier developmental stages of the type-1 form.

Attached to the surface of some of the large type-1 spheres are one to several club-shaped structures (e.g., Fig. 2C). This association is strikingly similar morphologically to a peronosporomycete oogonium to which are attached several paragynous antheridia (for details, see Dick $1969,1995,2001)$. It is interesting that among the type- 2 and type- 3 spheres are also specimens that show a similar association between the large spheres and smaller ones (e.g., Figs 3E-I, 4C-E). In contrast to type 1, in which there may be multiple small spheres attached to the wall, these other forms have only a single sphere attached. We cannot rule out that the small(er) spheres represent type- 1 specimens which incidentally became closely associated and perhaps physically connected with the type-2 and type- 3 spheres. The frequency of occurrence (i.e. in $~ 50 \%$ of the type- 2 and $\sim 25 \%$ of the type- 3 specimens), however, and the fact that constellations with more than one small(er) sphere have not been found, argue against the interpretation of these associations as incidental. We therefore wonder whether types 2 and 3 also represent some type of peronosporomycete oogonium to which are adpressed single paragynous antheridia. On the other hand, in this type of association the small spheres are sometimes quite large and thick-walled (e.g., in Figs 3I, 4D), a condition that may perhaps contradict affinities with the Peronosporomycetes. An alternative hypothesis is that the type- 2 and type- 3 spheres represent members of the Zygomycota. According to this

Figure 4. A, B - type-3 spheres characterized by prominent verrucate ornamentation; bars $=5 \mu \mathrm{m}$. $\bullet \mathrm{C}$ - verrucate sphere with smaller sphere attached; note separate parental hyphae of the spheres (arrows); bar $=10 \mu \mathrm{m} . \bullet \mathrm{D}, \mathrm{E}$ - verrucate spheres with smaller spheres attached; note differences in size and level of translucency between the three smaller spheres attached (arrows); bars $=10 \mu \mathrm{m}$. $\bullet \mathrm{F}-$ thin-walled type-5 sphere attached to host cell wall; bar $=10 \mu \mathrm{m} . \bullet \mathrm{G}-\mathrm{I}$ - thin-walled type- 6 structures interpreted as empty zoosporangia; arrows in Fig. $4 \mathrm{G}$ and $\mathrm{H}$ indicate what appear to be discharge openings; bars $=20 \mu \mathrm{m}$ (Fig. 4G) and $10 \mu \mathrm{m}$ Fig. 4H, I). $\bullet \mathrm{J}-$ spherical structure showing penetration hypha (arrows) and early stage in callosity development; note the more prominent, tube-like callosity to left of hypha; bar $=10 \mu \mathrm{m}$. $\bullet \mathrm{K}-\mathrm{M}$ - small cone-shaped callosities extending from host cell walls into cell lumen; bar $=10 \mu \mathrm{m}$. 
Michael Krings et al. • A fungal community in plant tissue from the Lower Coal Measures of Great Britain

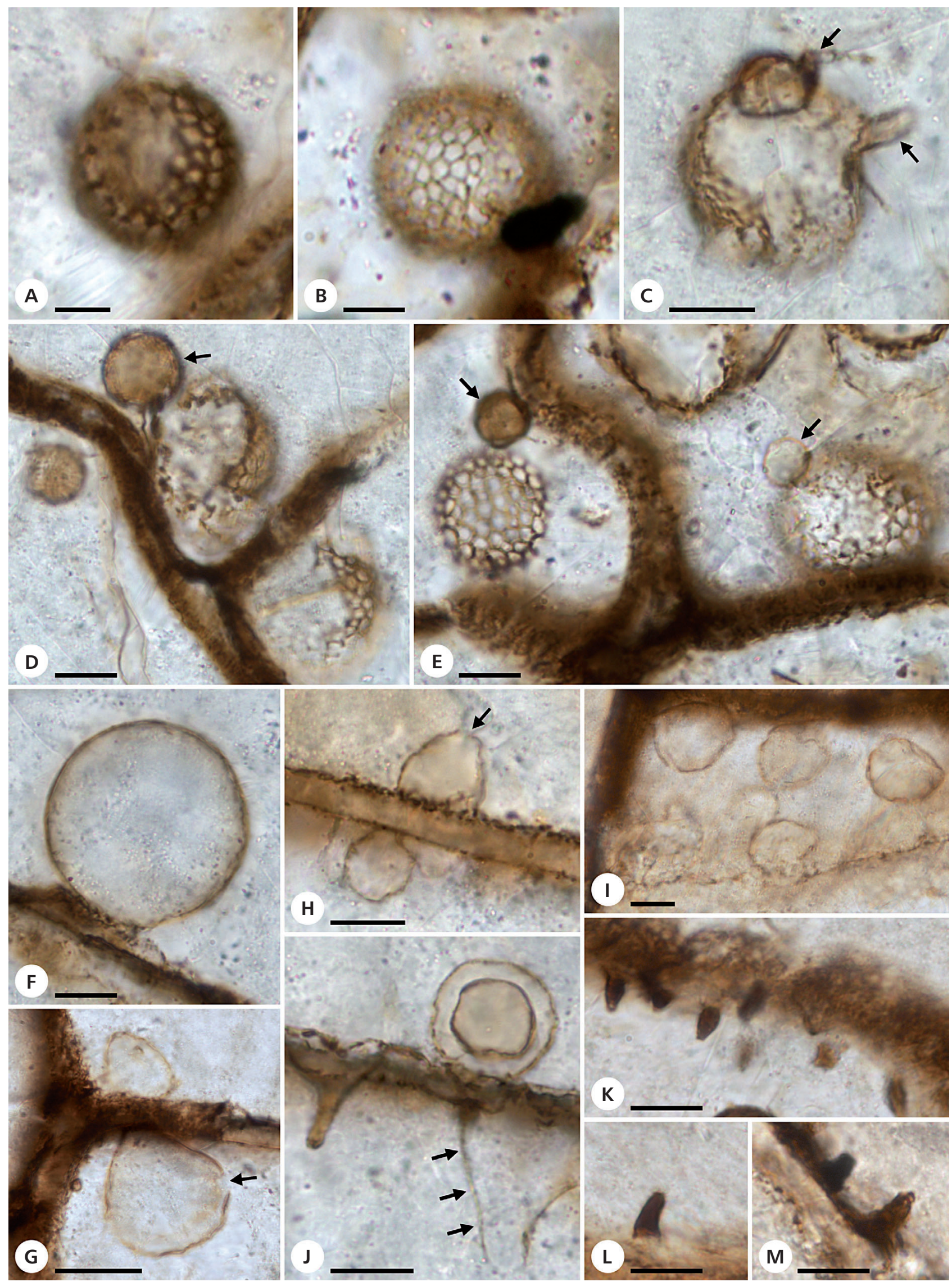



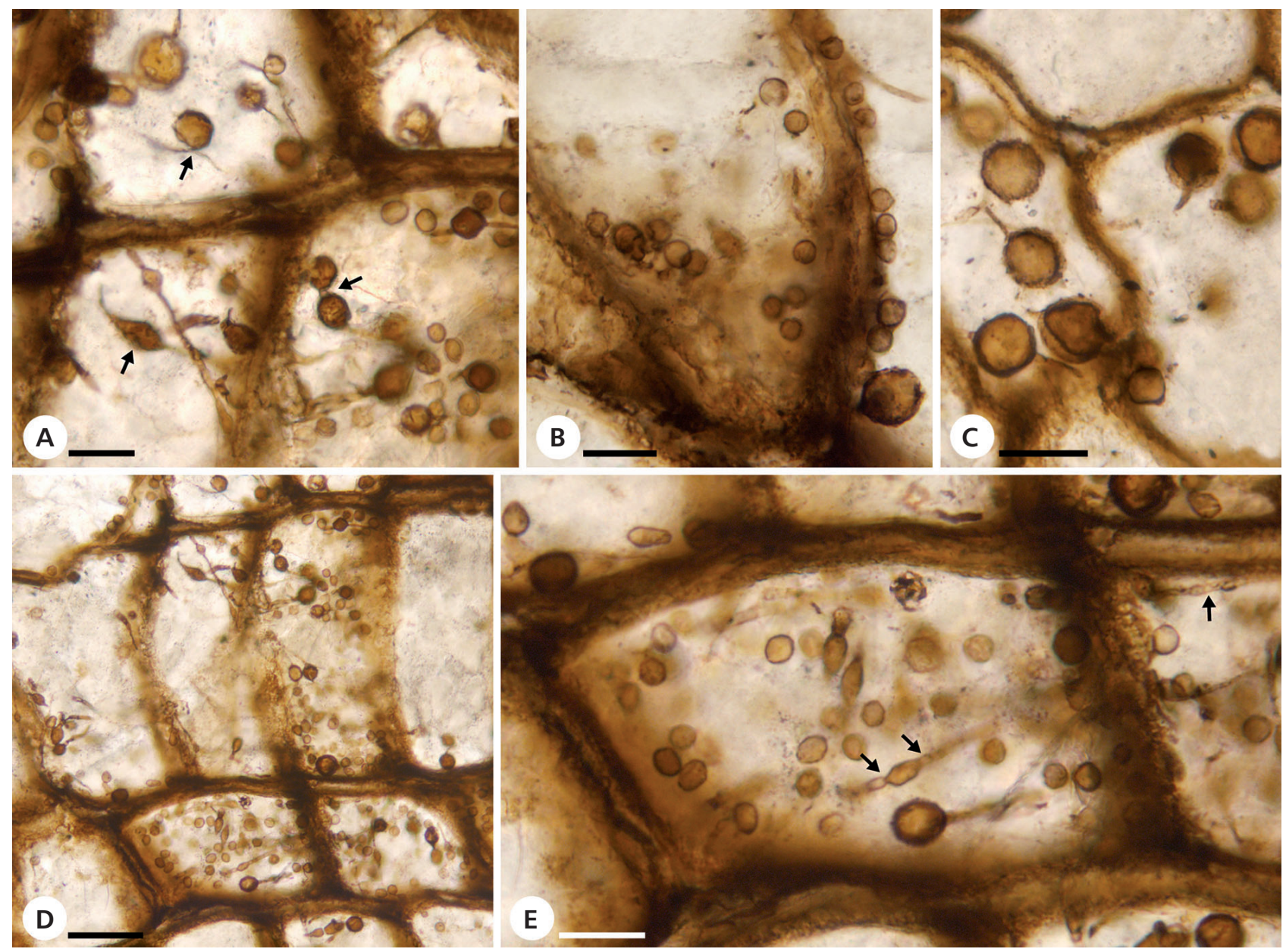

Figure 5. A-E - region of the periderm in which fungal remains are highly concentrated. $\bullet$ A-C, E- details of fungal remains in this region, showing intercalary swellings or spores (arrows in Fig. 5A), catenulate hyphae (arrows in Fig. 5E), and highly concentrated small (Fig. 5B) and large (Fig. 5C) spheres morphologically similar to types 4 and 1 ; bars $=20 \mu \mathrm{m}$. $\bullet \mathrm{D}$ - note concentration of fungal remains in a single cell; bar $=50 \mu \mathrm{m}$.

interpretation, the large sphere would be the zygosporangium, while the smaller ones represent the suspensor. The massive ephemeral wall or outer wall layer of the type- 2 spheres would represent the zygosporangial wall that gradually disintegrated once the zygospore became fully developed. If this hypothesis is accurate, then these fossil zygomycetes have produced one prominent and one undifferentiated, inconspicuous suspensor (see Benny et al. 2001). Unfortunately, wall features are of little help in distinguishing specimens as either related to the Peronosporomycetes or Zygomycota since thick-walled and/or prominently ornamented oogonia/sporangia occur in both groups (e.g., Zycha et al. 1969; Benjamin 1979; Dick 1995, 2001). Moreover, it has been shown in several Carboniferous peronosporomycetes that oogonial wall features can differ from those seen in any extant member of this group (Dotzler et al. 2008, Krings et al. 2010a). Since this may also be the case in fossil Zygomycota, wall thickness and composition are of little value in determining the affinities of these spheres. What can be stated with some certainty, however, is that the large spheres do not represent some form of outgrowth from the small spheres (as, for instance, in apophysate chytrid zoosporangia; for details, see Karling 1977), or the reverse, because there are several specimens showing that each sphere has its own stalk or subtending hypha (e.g., Figs 3G, 4C). One final thought on the possible affinities of these structures is that some of the small spheres might represent mycoparasites.

The other, rather infrequent fungal remains in the periderm (types 4 through 6 ) are even more difficult to attribute to any larger fungal group. One of the characteristics of type 6 are spherical to pear-shaped, thin walled structures that typically are slightly deformed, and a broadly attached to the cell wall (Fig. 4G-I). We interpret these as zoosporangia of a chytrid (Chytridiomycota) or chytrid-like organism (e.g., Hyphochytridiomycota) that have already discharged the zoospores; the specimen illustrated in Fig. 4J may represent a sporangium of the same type that is immature. Some of the ovoid or drop-shaped structures (type 4; Fig. 2G, H, J-L) may represent some 
type of anamorphic stage in a fungal life history. This suggestion has some merit since these typically occur in clusters arising from a common point or well-defined chains (e.g., Adams 1994, Hennebert \& Sutton 1994). Moreover, there are areas in the periderm in which there are catenulate hyphae with irregular swellings that may represent stages of coniodiogenesis (Fig. 1F-H). Whether they represent one or several types of conidia cannot be determined. In one region of the periderm are cells that contain large numbers of small ovoid bodies of the type-4 form as well as catenulate hyphae (Fig. 5E), which might suggest that these two structures represent different stages of the same organism. Many of the bodies in these host cells possess opposite attachment scars, suggesting that they were in fact produced in chains. Among the small bodies in this region of the host tissue are larger spheres (Fig. 5C) that resemble the type-1 morphology. The relationship between these latter structures and the catenulate hyphae and small bodies remains unclear.

\section{Conclusions}

There has been an increasing body of evidence in recent years documenting that within the Carboniferous swamp forest ecosystems there were extensive and diverse assemblages of microorganisms, mainly fungi and fungus-like organisms such as peronosporomycetes (see Krings et al. in press b). In several instances the microorganisms were identified as endophytes of certain types of land plants, including arborescent lycophytes as described in this paper. These plants produced great amounts of biomass, and thus probably provided the most important carbon source for the ecosystem saprotrophs and parasites. The large number of microbial remains within lycophyte tissues has made it possible in a few cases to place the endophytes systematically and piece together stages in their life history biology (e.g., Dotzler et al. 2008); in other instances, however, endophytic microfossils associated with land plants remain difficult, if not impossible to interpret (e.g., Krings et al. 2010b). We believe that this report, which describes diverse microfungi in lycophyte periderm from the Lower Coal Measures of Great Britain, adds important information about the biodiversity of fungi and fungus-like organisms in Carboniferous coals swamp communities, and also provides a new source of data that can be incorporated into the understanding of the complexity and interrelatedness of all components of these palaeoecosystems. While there is an increasing awareness and interest in the microbial component of modern ecosystems and their importance as drivers and sustainers in ecosystem function, we are only beginning to decipher their complexities in the fossil record. We hope that this paper not only highlights the excellent preservation potential of fossil fungi in coal balls, but also stimulates interest in these organisms, and encourages other researchers to prepare and study thin sections of coal ball material in their collections for fungi and other microorganisms.

\section{Acknowledgments}

This study was supported by funds from the National Science Foundation (EAR 0542170 and EAR-0949947 to T.N.T. and M.K.) and the Alexander von Humboldt-Foundation (V-3.FLF-DEU/1064359 to M.K.). The paper greatly benefited from the constructive comments and suggestions of Jason Hilton (Birmingham, Great Britain) and Hans Kerp (Münster, Germany).

\section{References}

AdAms, T.H. 1994. Asexual sporulation in higher fungi, 367-382. In Gow, N.A.R. \& GADD, G.M. (eds) The Growing Fungus. Chapman \& Hall, London.

Aist, J.R. 1977. Mechanically induced wall appositions of plant cells can prevent penetration by a parasitic fungus. Science 197, 568-570. DOI 10.1126/science.197.4303.568

Archer, K.J. \& Cole, A.L.J. 1986. Cuticle, cell wall ultrastructure and disease resistance in maidenhair fern. New Phytologist 103, 341-348.

DOI 10.1111/j.1469-8137.1986.tb00620.x

BenJAmin, R.K. 1979. Zygomycetes and their spores, 573-621. In Kendrick, B. (ed.) The Whole Fungus. Volume II. The Sexual-Asexual Synthesis [Proceedings of the $2^{\text {nd }}$ International Mycological Conference held at the Environmental Sciences Centre of the University of Calgary Kananaskis, Alberta, Can$a d a]$. National Museum of Natural Sciences, National Museums of Canada, and the Kananaskis Foundation, Ottawa.

Benny, G.L., Hamber, R.A. \& Morton, J.B. 2001. Zygomycota: Zygomycetes, 113-146. In McLoughlin, D.J., McLoughlin, E.G. \& LemKe, P.E. (eds) The Mycota. Volume VII. Systematics and Evolution. Part A. Springer-Verlag, Berlin.

Bhattacharya, D., Yoon, H.S., Hedges, S.B. \& Hackett, D. 2009. Eukaryotes, 116-120. In Hedges, S.B. \& KumAR, S. (eds) The Timetree of Life. Oxford University Press, New York.

BinNeY, E.W. 1865. A description of some fossil plants showing structure found in the lower coal-seams of Lancashire and Yorkshire. Philosophical Transactions of the Royal Society, London 155, 579-604. DOI 10.1098/rstl.1865.0011

CASH, W. \& Hick, T. 1879. On fossil fungi from the Lower Coal-Measures of Halifax. Proceedings of the Yorkshire Geological and Polytechnical Society 7, 115-121. DOI 10.1144/pygs.7.2.115

Colwell, R. 1998. Balancing the biocomplexity of the planet's living systems: a $21^{\text {st }}$ century task for science. BioScience 48 , 786-787. DOI 10.2307/1313389

Dick, M.W. 1969. Morphology and taxonomy of the Oomycetes, with special reference to Saprolegniaceae, Leptomitaceae and Pythiaceae. New Phytologist 68, 751-775. DOI 10.1111/j.1469-8137.1969.tb06478.x

Dick, M.W. 1995. Sexual reproduction in the Peronosporomycetes (chromistan fungi). Canadian Journal of Botany 73 (Supplement 1), S712-S724. DOI 10.1139/b95-314 
Dick, M.W. 2001. Straminipilous Fungi. Systematics of the Peronosporomycetes Including Accounts of the Marine Straminipilous Protists, the Plasmodiophorids and Similar Organisms. 670 pp. Kluwer Academic Publishers, Dordrecht, Boston, London.

Dotzler, N., Krings, M., Agerer, R., Galtier, J. \& Taylor, T.N. 2008. Combresomyces cornifer gen. sp. nov., an endophytic peronosporomycete in Lepidodendron from the Carboniferous of central France. Mycological Research 112, 1107-1114. DOI 10.1016/j.mycres.2008.03.003

ELLIS, D. 1918. Phycomycetous fungi from the English Lower Coal measures. Proceedings of the Royal Society of Edinburgh $38,130-145$.

GALtier, J. 1997. Coal-ball floras of the Namurian-Westphalian of Europe. Review of Palaeobotany and Palynology 95, 51-72. DOI 10.1016/S0034-6667(96)00027-9

GREEN, D.G. \& SADEDIN, S. 2005. Interactions matter - complexity in landscapes and ecosystems. Ecological Complexity 2, 117-130. DOI 10.1016/j.ecocom.2004.11.006

Hass, H. \& Rowe, N.P. 1999. Thin sections and wafering, 76-81. In Jones, T.P. \& Rowe, N.P. (eds) Fossil Plants and Spores: Modern Techniques. The Geological Society, London.

Hass, H., TAYLOR, T.N. \& REMY, W. 1994. Fungi from the Lower Devonian Rhynie chert: mycoparasitism. American Journal of Botany 81, 29-37. DOI 10.2307/2445559

Heckman, D.S., Geiser, D.M., Eidell, B.R., Stauffer, R.L., Kardos, N.L. \& Hedges, S.B. 2001. Molecular evidence for the early colonization of land by fungi and plants. Science 293, 1129-1133. DOI 10.1126/science.1061457

Hennebert, G.L. \& Sutton, B.C. 1994. Unitary parameters in conidiogenesis, 65-76. In Hawksworth, D.L. (ed.) Ascomycete Systematics: Problems and Perspectives in the Nineties [Nato Science Series A, vol. 269]. Plenum Press, New York.

Howell, A.C. 2005. James Lomax (1857-1934): palaeobotanical catalyst or hindrance?, 137-152. In BOwDEN, A.J., BUREK, C.V. \& WiLding, R. (eds) History of Palaeobotany: Selected Essays [Special Publications 241]. The Geological Society, London.

KARLING, J.S. 1977. Chytridiomycetarum Iconographia. An Illustrated and Brief Descriptive Guide to the Chytridiomycetous Genera with a Supplement of the Hyphochytridiomycetes. viii + 414 pp. J. Cramer, Vaduz.

KeRP, H. 2000. The modernization of landscapes during the late Paleozoic-early Mesozoic, 79-113. In Gastaldo, R.A. \& DiMichele, W.A. (eds) Phanerozoic Terrestrial Ecosystems. Paleontological Society Papers 6.

Krings, M., Dotzler, N., Galtier, J. \& TAylor, T.N. 2009. Microfungi from the upper Visean (Mississippian) of central France: Chytridiomycota and chytrid-like remains of uncertain affinity. Review of Palaeobotany and Palynology 156, 319-328. DOI 10.1016/j.revpalbo.2009.03.011

Krings, M., Dotzler, N., Galtier, J. \& TAYlor, T.N. In press a. Oldest fossil basidiomycete clamp connections. Mycoscience.

Krings, M., Dotzler, N., Taylor, T.N. \& Galtier, J. 2007. A microfungal assemblage in Lepidodendron from the Upper Visean (Carboniferous) of central France. Comptes Rendus Palevol 6, 431-436. DOI 10.1016/j.crpv.2007.09.008

Krings, M., TAYloR, T.N. \& Dotzler, N. In press b. Fungal endophytes as a driving force in land plant evolution: evidence from the fossil record. In Southworth, D. (ed.) Plant Fungal
Interactions - Interdependence between Plants and Fungi. ISUP/John Wiley \& Sons, Inc., Ames IA.

Krings, M., Taylor, T.N., Galtier, J. \& Dotzler, N. 2010a. A fossil peronosporomycete oogonium with an unusual surface ornament from the Carboniferous of France. Fungal Biology 114, 446-450. DOI 10.1016/j.funbio.2010.03.006

Krings, M., Taylor, T.N., Galtier, J. \& Dotzler, N. 2010 b. Microproblematic endophytes and epiphytes of fern pinnules from the Upper Pennsylvanian of France. Geobios 43, 503-510.

Moerschbacher, B. \& Mendgen, K. 2000. Structural aspects of defense, 231-277. In SlusarenKo, A.J., FraSER, R.S.S. \& VAN Loon, L.C. (eds) Mechanisms of Resistance to Plant Disease. Kluwer Academic Publishers, Dordrecht.

Phillips, T.L., Peppers, R.A. \& DiMichele, W.A. 1985. Stratigraphic and interregional changes in Pennsylvanian coalswamp vegetation: environmental inferences. International Journal of Coal Geology 5, 43-109. DOI 10.1016/0166-5162(85)90010-2

Rioux, D. \& Biggs, A.R. 1994. Cell wall changes in host and nonhost systems: microscopic aspects, 31-44. In PeTRINI, O. \& Ouellette, G.B. (eds) Host Wall Alterations by Parasitic Fungi. APS Press, St. Paul.

Stubblefield, S.P. \& TAYloR, T.N. 1988. Recent advances in paleomycology. New Phytologist 108, 3-25. DOI 10.1111/j.1469-8137.1988.tb00200.x

Stubblefield, S.P., Taylor, T.N., Miller, C.N. \& Cole, G.T. 1984. Studies of Paleozoic fungi. III. Fungal parasitism in a Pennsylvanian gymnosperm. American Journal of Botany 71, 1275-1282. DOI 10.2307/2443652

Taylor, T.N., Klavins, S.D., Krings, M., TAYlor, E.L., Kerp, H. \& Hass, H. 2004. Fungi from the Rhynie chert: A view from the dark side. Transactions of the Royal Society of Edinburgh, Earth Sciences 94, 457-473.

TAYLOR, T.N. \& KRINGS, M. 2005. Fossil microorganisms and land plants: associations and interactions. Symbiosis 40, $119-135$.

TAYlor, T.N., TAYlor, E.L. \& Krings, M. 2009. Paleobotany. The Biology and Evolution of Fossil Plants, $2^{\text {nd }}$ edition. xxi + 1230 pp. Elsevier/Academic Press, New York, NY.

WeIss, F.E. 1904. A mycorrhiza from the Lower Coal Measures. Annals of Botany 18, 255-265.

Williamson, W.C. 1880. On the organization of the fossil plants of the Coal-Measures. Part X. Including an examination of the supposed radiolarians of the carboniferous rocks. Philosophical Transactions of the Royal Society of London 171, 493-539. DOI 10.1098/rstl.1880.0014

Williamson, W.C. 1881. On the organization of fossil plants of the Coal-Measures. Part XI. Philosophical Transactions of the Royal Society of London 172, 283-305.

DOI 10.1098/rstl.1881.0003

Williamson, W.C. 1883. On the organization of the fossil plants of the Coal-Measures. Part XII. Philosophical Transactions of the Royal Society of London 174, 459-475.

DOI 10.1098/rstl.1883.0011

YounG, P.A. 1926. Penetration phenomena and facultative parasitism in Alternaria, Diplodia, and other fungi. Botanical $\mathrm{Ga}$ zette 81, 258-279. DOI 10.1086/333605

Zycha, H., Siepmann, R. \& Linnemann, G. 1969. Mucorales. Eine Beschreibung aller Gattungen und Arten dieser Pilzgruppe. viii + 355 pp. Verlag von J. Cramer, Lehre. 